University of Nebraska - Lincoln

DigitalCommons@University of Nebraska - Lincoln

To Improve the Academy

Professional and Organizational Development Network in Higher Education

1997

Improving Teaching Through Faculty Portfolio Conversations

Patricia Hagerty

Kenneth Wolf

Barbara Whinery

Follow this and additional works at: https://digitalcommons.unl.edu/podimproveacad

Part of the Higher Education Administration Commons

Hagerty, Patricia; Wolf, Kenneth; and Whinery, Barbara, "Improving Teaching Through Faculty Portfolio Conversations" (1997). To Improve the Academy. 377.

https://digitalcommons.unl.edu/podimproveacad/377

This Article is brought to you for free and open access by the Professional and Organizational Development Network in Higher Education at DigitalCommons@University of Nebraska - Lincoln. It has been accepted for inclusion in To Improve the Academy by an authorized administrator of DigitalCommons@University of Nebraska - Lincoln. 
Hagerty, P., Wolf, K., \& Whinery, B. (1997). Improving teaching through faculty portfolio conversations. In D. DeZure (Ed), To Improve the Academy, Vol. 16 (pp. 317-334). Stillwater, OK: New Formms Press and the Professional and Organizational Development Netwark in Higher Education. Key Words: Faculty Development, Discussions, Portfolios.

\section{Improving Teaching Through Faculty Portfolio Conversations}

\section{Patricia Hagerty}

\section{Kenneth Wolf}

University of Colorado at Denver

\section{Barbara Whinery}

University of Northem Colorado

The authors recount their experiences using portfolios of their teaching as the basis for conversations with colleagues and students about their teaching effectiveness. The authors identify a number of features that affected the quality of these conversations, including group composition, individual commitment, artifact collection. and conversation structure. The authors conclude that these portfolio conversations enabled them to develop insights into their teaching that they might not have been able to gain otherwise.

I had won several teaching awards and had been selected more than once by students for Mortarboard's outstanding professor award. My course evaluations were usually top-notch. But something nagged at me about my teaching. There were so many things I didn't like: the many assignments that required writing as a response to reading, the lack of choice on the part of my students as to the texts they would read, 
and the fact that points I awarded for assignments always decided a student's grade.

When the opportunity arose to join a group of colleagues developing teaching portfolios as a way to enrich their teaching, I readily jumped at the chance to enter into conversations that I hoped would lead to improvement in my own teaching. Little did I know how much I would learn or how much it would affect my classroom instruction

- Pat Hagerty

In the reflection above, and the ones that follow, we recount our experiences using teaching portfolios as the basis for conversations with colleagues and students about our teaching effectiveness. We engaged in this process to improve as teachers and to practice what we preach as teacher educators who ask our students to prepare their own teaching portfolios. The purpose of this article is to describe what we learned about the process of using teaching portfolios to focus on meaningful and productive discussions to improve instruction.

While many scholars have written about the value of teaching portfolios for assessing and promoting teaching effectiveness, few accounts exist of teaching portfolios in practice. We begin to address this void by reporting on our experiences as a group engaged in discussions of our teaching portfolios. Before we tell our story, however, we will first briefly describe the concept of a teaching portfolio.

\section{Teaching Portfolios}

A national movement to improve teaching effectiveness has been underway in higher education (Boyer, 1990) and in K-12 teaching (Goodlad, 1990). A number of scholars have proposed teaching portfolios as one vehicle for enhancing instructional quality. Edgerton, Hutchings, and Quinlin (1990), for example, discuss the role that portfolios can play in promoting university teaching and frame a number of issues that should be considered when constructing teaching portfolios. Seldin $(1991,1994)$ has written two books that describe essential elements and contain actual excerpts from faculty teaching portfolios. Additionally, teaching portfolios are being introduced in $\mathrm{K}-12$ settings, and higher education faculty may be able to learn from 
these experiences as well (Shulman, 1988; Bird, 1990; Wolf, 1991, 1994; 1996; Wolf \& Dietz, in press).

At its most basic, a teaching portfolio is a collection of information about a teacher's instructional effectiveness. A portfolio can include a wide variety of information, including course syllabi, lesson plans, examples of student work, assessments of student performance, videotapes of teaching, peer-based observations, and student evaluations. In addition to work samples, brief explanatory captions and reflective commentaries written by the portfolio author help to contextualize and frame the portfolio contents (Wolf, 1994). From our perspective, however, a teaching portfolio is more than the contents of the portfolio; it is also the process by which these contents become a vehicle for improving teaching effectiveness.

We take our definition of a teaching portfolio from Shulman (1992):

A teaching portfolio is the structured documentary history of a set of coached or mentored accomplishments substantiated by samples of student work and fully realized only through reflective writing, deliberation, and serious conversation.

We believe, along with Shulman, that teaching portfolios do not fully realize their value until the contents have become a departure point for substantive individual reflections and collegial conversations about teaching.

\section{Portfolio Conversations}

Although from different institutions, we all shared a common interest in teaching portfolios and a strong desire to improve as teachers. With the support of a small faculty development grant (a course release for Barb Whinery to organize the sessions), we decided to prepare portfolios of our teaching and meet regularly to discuss our teaching. We also sought to engage others in these discussions.

In forming our portfolio conversation group, we began by considering who should be in the group and how often we should meet. We decided that the group had to include subject matter counterparts for each portfolio author, otherwise issues of content and content pedagogy could not be dealt with in substantive ways. We also invited other 
colleagues who had insights into teaching and would be willing to give honest, thoughtful feedback. We felt it was important to invite a graduate teaching assistant to participate because we wanted to model a reflective approach to teaching as well as gain a student perspective on our teaching. Our particular group ultimately included two instructors whose specialty was literacy instruction (Pat Hagerty and a counterpart); two instructors whose specialty was middle school education (Barb Whinery and a counterpart); two who taught various courses in teacher education (Kenneth Wolf and a counterpart), and a doctoral student in middle school education.

After we formed our group, we decided to hold four two-hour meetings during a single semester to discuss our teaching. Pat and Barb volunteered to be the portfolio authors who would present their artifacts and discuss their teaching, with each taking the lead at two of the four meetings.

Our plans for these sessions were initially open-ended. We each brought in an artifact or two, explained issues related to our teaching, and requested feedback. Based on our experiences, we refined this process into four steps, which are explained in a later section.

In the commentaries that follow, we will focus in particular on the conversations that we held with our colleagues and students about our teaching and the ways in which these conversation did (and did not) contribute to our development as teachers. We do not hold out the process we describe as a model for others to emulate, but instead we hope our reflections will productively stimulate the thinking of others as they build their own portfolios and engage their colleagues in discussions about teaching.

\section{Session 1: Talking about Teaching}

\section{Presenter Commentary: Pat Hagerty}

I looked through my in-progress portfolio and chose to bring four "artifacts" to the portfolio group. These artifacts were a course outline, a videotape of my teaching, examples of students' attempts at reflection, and samples of student evaluations of previous courses.

At the first meeting, I presented the course outline for a graduate language arts course I was teaching. I asked the group for their 
opinions on three of the assignments. Each of the assignments required the students to read books and journals related to the topics that would be studied in the class and to respond in writing to the following questions:

(1) "What struck you or stood out to you?"

(2) "What questions do you have?"

(3) "What might the information mean for your own teaching?"

I asked my colleagues two specific questions: "How can I have students respond to their reading in a way that will be more interesting both to them and me?" and "Do you think I have too many assignments in which students are asked to read and respond?"

As I shared my own reflections about this dilemma, I explained to the portfolio group that I believed strongly in choice leading to ownership, whether it is in the elementary or university classroom. In fact, to "walk my talk," I had, just for this class, asked the students to choose their own writing process text from among seven I had selected and a text on teaching spelling from among six I had selected. I also wanted to extend the idea of choice to the assignments, but for some reason I could not come up with a way to do this. I also explained that as I tried to put myself in the place of my students, I realized I would not want to do all that writing. And I shared that I personally believed that some of the students wouldn't read the texts if they did not have to respond in some way.

One group member recalled having some of the same concerns about her own assignments. She had taught an undergraduate social studies course and had given students the choice to respond to their reading through writing or orally on tape. She listened to the tapes while commuting and responded to her students using the same tape. I liked her idea and thought I might be able to try it in my course.

In response to my second question about whether I had too many assignments, the group answered with a resounding "yes." They suggested that I cut back on the number of journal articles I asked the students to read and to consider changing a final project that required the students to read three additional texts from a list I had developed.

On the basis of the comments and reflection from the portfolio group, I reduced the number of journal articles I asked the students to read from six to three. I also changed the final assignment: students 
could choose their own way of showing what they had learned in class or they could read and respond to the three additional texts.

My biggest change involved the responses to reading. I decided that I would ask the students to respond to one of the required texts through writing, a second one by reflecting upon it orally on tape, and the third one through an "artistic" response. As I stood up in front of the class to announce the changes in the assignments, I changed my mind one more time! I told the students they could respond to any of the readings (three required texts, three journal articles) in either of the three ways. I left the definition of "artistic" up to the students, but we did discuss ideas that might be used.

The students were excited. They did not mind at all that I had changed the assignments at the second class session, especially after I explained to them that I was a member of a group of colleagues interested in improving our own teaching. I have to say that these assignments turned out to be some of the best I had ever received from students. I enjoyed listening to the tapes while I commuted. The artistic responses were very creative and, for the most part, captured what we had been learning. These responses ranged from videotapes of students trying out what they learned from the readings to eye-catching posters to "kits" that contained all the materials needed for a Writers' Workshop. Interestingly, many of the students chose to respond in writing because they felt more comfortable with that process.

In the end, based on just one meeting with my group of colleagues, I changed my teaching in ways that benefited both the students and myself. Being a part of the group gave me the encouragement I needed to get started and the support I needed to continue.

\section{Colleague Commentary: Barb Whinery}

As Pat presented her artifacts and asked questions about her teaching, I began to reflect on my own teaching practices and issues. In response to her comments about "walking her talk," I found myself reflecting on the importance of modeling effective teaching behaviors and began assessing how I was accomplishing this goal in my own teaching. Demonstrating the methods that I am advocating for my students to use as prospective teachers is very important to me as a teacher educator. I have been very critical of teachers and professors 
who advocate a variety of approaches to teaching and then proceed to lecture for an entire semester. After listening to Pat's comments, I began to think: 'Was I just another 'sage on the stage' or was Ia 'guide on the side' as I wanted to be?"My fear was that I, too, had fallen into the lecture syndrome more often than using strategies that I had advocated for my students, such as cooperative grouping or an inquiry approach to learning.

Another comment by Pat that triggered my thinking was related to the fact that she had indicated that she was a "good presenter" but had begun to question whether or not she was a "effective teacher." I, too, believed I was a "good presenter," but the question I was now asking myself was, "What are my students learning?" Class discussions, midterm examinations, and projects seemed to indicate they had acquired the knowledge I had intended them to learn, but as I followedup on field experiences, I observed very little application of concepts and theories I thought I had taught or they had learned in my class.

It was interesting to hear other members in the group share their recommendations and observations concerning the course syllabus. Although my background was not in literacy, I felt, as did others, that we could make recommendations for changes in Pat's course outline. I believe we were able to give Pat ideas on how to vary her class assignments and coordinate those assignments with the course objectives. The suggestions given to her helped me analyze my own course syllabus for the variety of activities that I require. I wondered whether my assignments included group as well as individual activities, and whether I provided some choices for students in completing those assignments.

\section{Session 2: Learning from Students}

\section{Presenter Commentary: Pat Hagerty}

At our university, one of our goals is to graduate reflective practitioners. Helping students learn to be reflective about their own teaching and that of others is one of our most important-and most difficult - jobs. In the methods courses we teach, students have a field component called "cadet teaching." In cadet teaching, I ask students to keep a journal for each day they are in a classroom, outlining what 
they did or saw, giving their reflections, and describing how they would change that and why. Of the 25 students in the class, only a few journal entries showed evidence of good reflection. I brought these journals to the portfolio group and asked how I could get more of my students to be reflective about their cadet teaching experiences and the teaching they observed while in the field.

As I talked with my colleagues about my attempts to get my students to reflect, not just report what they did or saw, my frustration mounted. I explained that I had shown transparencies of papers that demonstrated good reflection, and read them over with the students while pointing out reflective parts. I also wrote an " $R$ " next to places in their journals, which were handed in weekly, where they revealed even a glimmer of reflection. What else could I do?

In the conversation that followed, one member of the group noted that the papers showing what I believed to be good reflection were written about lessons the students themselves had taught. None of the examples of good reflection was based on lessons the students had observed others teach. I had never noticed this before. What I learned was that better reflection came from doing, not just seeing. Real reflection had to start with the students' own teaching experiences.

One colleague suggested that I ask students to share their reflections in small groups so that they get feedback from more than just the instructor. Another member of the group suggested that specific questions be asked of the students so that they have something specific to look for and think about as they are in classrooms. She also noted that she wrote questions in the students' journals about their comments. She felt that these questions led to better opportunities to reflect.

Another colleague said she saw better reflection when she asked her students, before they taught a lesson, to write what they knew about the subject matter, about teaching that subject, and about the children they were going to teach. After they taught the lesson, they wrote about what they would do differently if they taught the lesson again as well as what they learned from teaching it.

I decided to implement these ideas. In the next course I taught, I found much more in-depth reflection from students about their own teaching. I also provided time in class for students to share their 
reflective journals with each other. Even their reflections about someone else's teaching got better, although these did not reach the same degree of insight as those based on their own teaching.

The second artifact I brought to the group that day was a summary of student evaluations from a course I had recently taught. These summary sheets simply tell the percentages of students' responses to each of 18 questions they are asked about my teaching. I also add some open-ended questions for students to answer. These questions included, for example: "What was the best thing about this course?," "What would you like to see changed in the course?," and "How has this course helped you grow professionally, if at all?" But these did not give me helpful information. My question to my colleagues was: "How can I get meaningful feedback that will really help improve my teaching?"

I explained how I distributed the course evaluations on the last day of class. The students completed them while I was out of the room. While in the process of describing this procedure, it dawned on me why the feedback was not very helpful -the students were in a rush. On the basis of the portfolio group's discussion, I decided that I would distribute the open-ended questions before the last day of class. This would enable students to take a week or so to complete what I hoped would be more thoughtful responses.

While in the process of describing my problems with course evaluations, I remembered how I had at one time asked students to give feedback about a course at mid-semester and had received helpful feedback which led me to change some assignments. The process of discussing my concerns with the group had enabled me to reach back in time and remember something that I had once done. I wanted to reinstate the mid-semester evaluation.

My colleagues also suggested that I might interview five students, after grades were determined, about their views of the way the class was taught. I have not implemented this yet, but it's in the plans.

Through this conversation, I learned that examples of student work and student evaluations provide perspectives that are essential in helping me reflect on my teaching. 


\section{Colleague Commentary: Barb Whinery}

When Pat began to ask questions about student evaluations, I realized that I shared many of the same concerns. To some degree, I had questioned the validity of the comments from students because I was not always sure that students knew how to evaluate my effectiveness as a teacher.

I had used many of the same questions as Pat had with her student evaluations at the end of the semester, but I had not considered using a mid-semester feedback form until we discussed it in the group. I usually relied on my own observations and unsolicited comments from students at mid-semester to evaluate my instruction and the course. As a result of this discussion, I plan to include mid-semester feedback and post-semester student interviews in future courses I teach.

I shared with the portfolio group a strategy for evaluating my own effectiveness that has worked well. I ask students to set three learning goals at the beginning of the semester. At the end of the semester, I ask them to comment in writing on whether they accomplished these goals, and why. This has provided me some valuable insight on the depth of their learning and at the same time provides me with some feedback on my own teaching. The mid-semester feedback, student interviews, and student personal goals and reflections will be important artifacts in my portfolio, and more importantly, provide valuable guidance for my teaching.

\section{Session 3: Reconsidering Our Goals and Strategies}

\section{Presenter Commentary: Barbara Whinery}

As I prepared for my presentation, it appeared that all I would have to do was to lead the group in discussion about some issues related to my teaching. I was in the beginning stages of putting my portfolio together and wanted to focus only on one artifact, a course syllabus from a class I was teaching.

My plan was to describe the context of the class and ask for feedback on how I had organized the class and represented it through the course syllabus. This was the first time I had taught this particular course and I was experiencing a great deal of frustration with how I 
had sequenced the content, selected the requirements, and was implementing the learning activities.

Iled the group in a variety of conversations, including many broad philosophical ones about the role of the teachers and learners in the classroom. I was truly struggling not only with what my students were learning, but also how they were going about it.

The conversations were very stimulating and provided me some food for thought. But looking back on this session, it really did not get at the heart of my teaching nor did it lead to changes that I could actually make in the delivery of the class. In my first experience as the presenter to the portfolio group, I did not realize that I had to be prepared to ask specific questions and ask for specific feedback from the members. I thought that I only had to start the conversation, lead the group in discussion, and record their comments about the various issues we addressed.

As a first time presenter, I felt a certain amount of fear about opening the doors of my classroom, even to respected colleagues. Afterwards, Pat and I discussed how different the feelings were between being a group member and the presenter. It takes time to develop trust with colleagues to reveal yourself as a teacher.

Because the group had such a broad focus, there was very little in the way of specific information that I could use to revise my course syllabus or make changes in my teaching. But all was not lost. I did learn more about the role of the portfolio presenter and what I needed to do to be more successful in that role. Several of the group members stayed afterward to provide feedback on my session, and, as a result of our conversations, we identified some strategies for leading the group in future meetings.

\section{Colleague Commentary: Kenneth Wolf}

After the meeting, Pat and I talked about what had transpired. We both found the conversation stimulating, but we were also vaguely dissatisfied with the session. We quickly realized that the main problem with the session was that the conversation focused on teaching in general, and not on specific features of Barb's teaching. The end result was a conversation that ambitiously addressed a number of substantive and lofty issues in education but did little to inform Barb's teaching. 
We ultimately recognized that our goal in these sessions should not be to address the problems with education in America or reform in teacher education, despite their critical importance. We realized that our goal should be a more modest (and attainable) one-to help the portfolio author improve his or her teaching.

Once we clarified our goals, Pat suggested that a good format for the sessions would be along the lines of Writers' Workshop (Atwell, 1987; Graves, 1983), a process approach to teaching writing. A key feature of Writer's Workshop is the "author's chair," in which writers share a piece of work and then get feedback from the audience members. In these sessions, the writer begins by asking the listeners for specific help (e.g., "I need help on how to end this."); and the listeners provide feedback based on the author's request. By focusing on the author's questions, the group members can provide help where the author believes it is most needed. In addition, focusing on the author's questions promotes ownership over the learning process and recognizes that we learn best when we have an interest in the questions being addressed.

While we believe that the portfolio conversations should emanate from the author's concerns, we continue to wrestle with the issue of striking a productive balance between addressing an author's questions while allowing group members to raise critical issues that the portfolio author may not have identified.

\section{Lessons Learned}

In this section, we discuss some of the lessons that we learned about teaching portfolios and collegial conversations.

Group composition. We originally decided that the portfolio group should be composed of: (a) at least one colleague whose subject matter knowledge and teaching responsibilities were similar to the portfolio author's, (b) other colleagues who brought special skills and interests to the conversation, and (c) one or more graduate students.

We found that this mix of expertise and perspectives worked well. However, we became even more convinced of the importance of enlisting a colleague with similar subject matter knowledge and teaching experience. We believe that only those deeply knowledgeable 
about the subject matter and the ways that it can be pedagogically represented could offer insights into the coherence and soundness of a portfolio author's instruction. The merit of this view was evidenced in Barb's situation, whose subject matter colleague was present at one meeting, but not the other. Barb reported that the session in which her subject matter colleague was in attendance was much more engaging and informative for her than when her colleague was not there.

As for group size, we wanted the group to be large enough to sustain a conversation, but small enough to allow everyone ample opportunity to contribute. With this in mind, we aimed for a regular group of six members. That number turned out to be right for us, but group size turned out to be less important than group consistency, as we discuss in the following section.

Individual Commitment. Making time and building trust are two important components of a successful portfolio group. All group members must make a firm commitment to attend all of the sessions. It is difficult to sustain a serious discussion if people wander in and out of the conversation, attending one session but not the next. When this happens, the conversations can resemble a cocktail party, where one-liners and superficial talk predominate.

Given the busy lives that faculty members lead, it is difficult to make time for a seemingly non-essential activity (that is, no immediate deadline looms). However, individual commitment can be greatly strengthened through institutional incentives. Our group had a modest, but valuable, contribution from Barb's university in the form of a course release for Barb Whinery and refreshments for the sessions. Others considering similar ventures are encouraged to seek institutional support as well in the form of course releases or research grants to help faculty members find time to prepare their portfolios and participate in portfolio conversations.

While a commitment to prepare materials and attend all of the sessions is necessary, it is not sufficient. For portfolio conversations to be truly productive, people also need to establish trust. The portfolio sessions are not intended to be a celebration of teaching successes (even though this often occurs), but rather an exploration of teaching dilemmas. That is, the sessions are most valuable when people honestly pose difficult questions and present complex problems they face 
in their teaching. If trust is not present, people will not reveal their weaknesses or worries.

Building trust is a delicate process, and it must occur over time as people share their ideas and test the responses of their colleagues. This process can be facilitated, we believe, if participation in the group is voluntary (even though incentives might be offered) and non-evaluative. If people are genuinely interested in improving their teaching, and they do not fear negative consequences, the conversations are more likely to be honest and productive.

Artifact Collection. We recognized that artifacts of teaching, such as course syllabi, are invaluable as departure points for discussing teaching. However, we also came to realize the critical value of artifacts of learning, such as student work. Artifacts of teaching provide information about the intended curriculum, but the artifacts of learning offer insights into the enacted curriculum. Both types of artifacts are valuable for understanding a teacher's effectiveness, but each offers different perspectives. All portfolios should have samples of both.

We fully realized the importance of student work when Pat brought in examples of student journals in which her students wrote about their initial teaching experiences and about their observations of others' instruction. Pat commented that only a few of these journal entries were reflective in nature, and she asked the group what she could do to foster greater reflectivity in her students.

It was only because Pat brought in actual samples of student writing that the group gained some insights into the problem. When the group members examined the journal entries, one member noticed that when students were writing about their own teaching experiences, they were reflective; but when writing about their observations of others, they were not. Pat was able to take this information, along with other suggestions that the group gave about stimulating reflection, and make modifications in her teaching, such as having students discuss their reflections in small groups before writing. Without looking at examples of student work, it is unlikely that the group would have discovered the connection between "seeing and doing" and reflectivity. 
Conversation Structure. Based on our experiences (both the successful and less-than-successful ones), we identified a number of features that foster productive portfolio conversations. We recommend a process for each session in which the portfolio author: (1) focuses on artifacts, (2) poses a problem or question, (3) invites feedback, and (4) designs an action plan (Wolf, Whinery, and Hagerty, 1995).

Focusing on actual artifacts keeps the conversation grounded in specific features of teaching. Having the portfolio author pose questions for the group to consider directs the discussion to dilemmas that the presenter is struggling with. Inviting the group to give feedback that addresses the portfolio author's concerns makes the feedback more relevant and useful for the presenter. Designing an action plan encourages the portfolio author to act on what was learned.

\section{Conclusion}

Both faculty members, Pat and Barb, who presented portfolios to the group felt that the portfolio process and ensuing conversations promoted their teaching effectiveness. Selecting artifacts to share, presenting those artifacts to a group of peers, reflecting on concerns, soliciting feedback about instruction, and determining a plan for change enabled each to examine more closely their own teaching and make more informed decisions.

Selecting and presenting artifacts, however, was only part of the process that led to better teaching. While we believe that a portfolio is necessary to allow for a careful examination of teaching, we do not believe that it is sufficient. Equally important is being a member of a group of peers who are interested in improving their teaching and who are willing to participate in formal and substantive conversations with their colleagues to accomplish that goal.

\section{References}

Atwell, N. (1987). In the middle: Writing. reading, and learning with adolescents. Portsmouth, NH: Heinemann.

Bird, T. (1990). The schoolteacher's portfolio: An essay on possibilities. In J. Millman \&

L. Darling-Hammond (Eds.), The new handbook of teacher evaluation: Assessing elementary and secondary school teachers (pp. 241-256). Newbury Park, CA: Sage. 
Boyer, E. (1990). Scholarship reconsidered: Priorities of the professoriate. Princeton, NJ: Carnegie Foundation for the Advancement of Teaching.

Edgerton, R., Hutching, P., \& Quinlin, X. (1991). The teaching portfolio: Capturing the scholarship of teaching. Washington, DC: American Aseociation of Higher Bducation.

Goodlad, J. (1990). Teachers for our nation's schools. San Francisco: Jossey-Bass Publishers.

Graves, D. (1983). Writing: Teachers and children at work. Portsmouth, NH: Heinemann.

Seldin, P. (1991). The teaching portfolio: A practical guide to improved performance and promotionalkenure decisions. Bolton, MA: Anker Publishing Co.

Seldin, P. (1994). Successful use of teaching portfolios. Bolton, MA: Anker Publishing Co.

Shulman, L. (1988). A union of insufficiencies: Strategies for teacher assessment in a period of reform. Educational Leadership, 47, 36-41.

Shulman, L. (1992). Portfolios for teacher education: A component of reflective teacher education. Presentation at the annual meeting of the American Educational Research Association, San Francisco, California.

Whinery, B. (1992). Using portfolios as a means of student assessment and to increase faculty collaboration for middle school and elementary teacher education programs. Proposal submitted to the Center on Teaching and Learning, College of Education, University of Northern Colorado, Greeley, CO.

Wolf, K. (1991). The schoolteacher's portfolio: Issues in design, implementation, and evaluation. Phi Delia Kappan, 73, 129-136.

Wolf, K. (1994). Teaching portfolios: Capturing the complexity of teaching. In L. Ingvarson \& R. Chadborne (Eds.), Valuing teachers' work: New directions in teacher appraisal (pp.112-136). Victoria, Australia: Australian Council for Educational Research.

Wolf, K. (1996). Developing an effective teaching portfolio. Educational Leadership, 53, 34-37.

Wolf, K., \& Dietz, M. (in press). Teaching portfolios: Purposes and possibilities. Teacher Education Quarterly.

Wolf, K., Whinery, B., \& Hagerty, P. (1995). Teaching portfolios and portfolio conversations: A powerful vehicle for improving teaching effectiveness. Action in Teacher Education, 27, 30-39.

Contact:

Patricia Hagerty

3224 3rd Street

Boulder, Colorado 80304

PTBCHAG@aol.com 
Patricia Hagerty is a faculty member at the University of Colorado at Denver and directs programs in literacy education. She has written extensively on literacy education and is currently the editor of the Colorado Reading Council Journal.

Kenneth Wolf, an assistant professor in the School of Education at the University of Colorado at Denver and Teacher of the Year in 1995, teaches graduate courses in the School of Education in research methods and classroom assessment. He has written extensively on the topic of portfolios for both students and teachers.

Barbara Whinery is an associate professor at the University of Northem Colorado where she coordinates the middle grades and secondary teacher education programs. Her research interests include middle school instruction, integrated curriculum, assessment and teacher education.

Acknowledgments: The authors would like to thank the other members of the portfolio group (Vicki Faircloth, Doug Macisaac, Christi Roper, and Hap Chamnell) for their contributions to this project. 